\title{
PENGEMBANGAN MODEL PEMBELAJARAN PPKn ANTI KORUPSI BERBASIS LINGKUNGAN MELALUI COOPERATIVE LEARNING DI SMA/SMK SWASTA KULON PROGO YOGYAKARTA
}

\author{
Oleh: \\ Nuryati, Triwahyu Budiutomo, Ahmad Nasir Ari Bowo \\ Universitas Cokroaminoto Yogyakarta
}

\begin{abstract}
Abstrak
Penelitian ini bertujuan 1) mengetahui penerapan pembelajaran PPKn yang dilaksanakan di SMA/SMK Swasta Kulon Progo Yogyakarta, 2) mengembangkan model pembelajaran PPKn Anti Korupsi berbasis lingkungan melalui cooperative learning di SMA/SMK swasta Kulon Progo Yogyakarta, 3) penerapan model pembelajaran PPKn Anti Korupsi berbasis lingkungan melalui cooperative learning di SMA/SMK swasta Kulon Progo Yogyakarta, 4) peningkatan pemahaman konsep dan prestasi akademik siswa setelah penerapan model. Pendekatan penelitian adalah research and development. Subjek penelitian ini adalah guru dan siswa SMA/SMK Swasta Kulon Progo Yogyakarta antara lain SMK Maarif 1 Wates, SMA Muhammadiyah Wates, SMK PGRI, SMK Maarif 3, SMA Bopkri, sebagai populasi uji coba. Tahapan pengembangan pendekatan deskriptif kualitatif, meliputi 1) studi literatur, 2) studi lapangan, 3) deskripsi dan analisis temuan lapangan.

Hasil penelitian 1) Di beberapa SMA/SMK di Kulon Progo dalam penyampaian materi PPKn oleh guru dapat diketahui antara lain a) Persiapan guru masih kurang. b) Guru belum sepenuhnya mengimplementasikan nilai anti korupsi. c) Pembelajaran kebanyakan di laksanakan di dalam kelas. d) Model yang di pakai oleh guru adalah ceramah, diskusi dan presentasi. e) guru belum mengembangkan model dengan maksimal. dan f) guru jarang melakukan display ruang kelas. 2) Langkah-langkah pengembangan model pembelajaran PPKn anti korupsi berbasis lingkungan melalui cooperative learning yaitu: a) tahap pendahuluan meliputi pemberian salam dan doa, menanyakan keadaan siswa, ice breaking, memotivasi siswa (nilai anti korupsi jujur, disiplin, tanggung jawab, peduli). b) tahap inti pembelajaran meliputi: penyajian secara umum, pengajuan membandingkan dan menjelaskan analogi, analogi tim, dan pengajuan analogi baru (nilai anti korupsi: jujur, disiplin, tanggung jawab, peduli). c) tahap penutup meliputi konfirmasi, kesimpulan dan tindak lanjut pertemuan berikutnya (nilai anti korupsi: jujur, disiplin, tanggung jawab, dan peduli). 3) Implementasi model pembelajaran PPKn anti korupsi berbasis lingkungan melalui cooperative learning di lakukan beberapa tahap. Pertama kali adalah tahap uji coba terbatas. Uji coba terbatas di terapkan pada kelas X TKR 2 SMK Maarif 1. Masih ada kekurangan dalam penerapan pada uji coba terbatas. tahap kedua adalah uji coba lebih luas diterapkan pada kelas X TKJ 1 SMK Maarif 1 dan kelas X SMA Muhammadiyah. Pada tahap ini pengajar sudah mampu menerapkan dengan baik. terakhir adalah tahap uji validasi pada kelas X AP SMK PGRI, kelas X AK SMK PGRI, X TSM SMK Maarif 3, X TKR SMK Maarif 3, dan SMA Bopkri Kulon Progo Yogyakarta. 4) Uji coba terbatas, uji coba lebih luas dan uji validitas menunjukkan peningkatan Pemahaman konsep siswa sebelum uji coba model adalah $59 \%$ setelah uji coba model menjadi $94 \%$, peningkatan pemahaman konsep siswa adalah 35\%. Prestasi akademik sebelum ujicoba 70,4\% setelah uji coba model $82 \%$. Peningkatan prestasi akademik siswa adalah $11,6 \%$.
\end{abstract}

Kata Kunci: Model, PPKn Anti Korupsi, Berbasis Lingkungan, Cooperative Learning, Pemahaman Konsep dan Prestasi Akademik 


\section{Pendahuluan}

Pembelajaran belum dikatakan berhasil apabila guru dalam proses pembelajarannya belum bisa menerapkan model pembelajaran yang memenuhi kriteria pembelajaran aktif, inovatif, kreatif, efesien, dan menyenangkan. Sudah terbukti bahwa masih banyak sekolah sampai sekarang ini, dalam proses pembelajaran guru belum mampu menerapkan model pembelajaran yang memenuhi unsur kriteria tersebut atau belum bisa mengembangkannya. Hal ini berakibat bahwa peserta didik belum mampu memahami dan mengimplemantasikan dengan baik materi yang di peroleh.

Beberapa contoh penelitian yang berkaitan tentang penerapan model pembelajaran dengan hanya menggunakan model ceramah, diskusi, dan penugasan. Salah satunya hasil penelitian yang dilakukan oleh Wahyuningsih (2014) di SMP Negeri 2 Jatipuro Karanganyar pada siswa kelas VIII B. Mengemukakan bahwa penerapan model ceramah, diskusi, dan penugasan oleh guru, belum mampu meningkatkan ketuntasan belajar siswa. Selain itu Perwira (2014) di SD Negeri 3 Jetis Kecamatan Jaten pada siswa kelas V, memperlihatkan bahwa model pembelajaran yang diterapkan oleh guru masih bersifat satu arah sehingga membentuk kejenuhan belajar yang memberikan pengaruh terhadap capaian ketuntasan hasil belajar yang rendah. Berdasarkan ke dua penelitian tersebut dapat di ambil kesimpulan bahwa masih banyak guru dalam mengajar di kelas belum menerapkan dan atau mengembangkan pembelajaran aktif, kreatif, efesien dan menyenangkan sehingga hasil belajarnya pun juga masih rendah.

Hasil wawancara peneliti dengan beberapa siswa yang mengikuti pembelajaran PPKn di beberapa SMA/SMK swasta Kulon Progo Yogyakarta, dapat disimpulkan bahwa masih ada guru dalam mengajar belum menggunakan pembelajaran anti korupsi dan memanfaatkan lingkungan sebagai media atau sumber pembelajaran secara maksimal. Selain itu pembelajaran yang sering di gunakan adalah ceramah bervariasi, diskusi, dan penugasan sehingga masih ada siswa yang kurang aktif dalam mengikuti pembelajaran, bahkan ada yang merasa jenuh dan mengantuk, ketika mengikuti pembelajaran. Dapat diketahui bahwa tujuan pembelajaran PPKn belum tercapai secara maksimal. Sehingga perlu ada pengembangan model pembelajaran. Hal tersebut bertujuan untuk memudahkan siswa dalam mencapai tujuan pembelajaran.

Berpedoman dengan hasil penelitian terkait keberhasilan pembelajaran anti korupsi berbasis lingkungan, penulis akan melakukan penelitian di beberapa SMA swasta sederajat Kulon Progo Yogyakarta, yang terdiri dari 5 sekolah. Adapun judul dalam penelitian ini 
adalah pengembangan model pembelajaran PPKn anti korupsi berbasis lingkungan melalui cooperative learning di SMA swasta Kulon Progo Yogyakarta.

Proses pemecahan masalah akan terarah dan terfokus apabila permasalahannya dapat dirumuskan secara jelas. Rumusan suatu masalah atau fokus penelitian ini yaitu.

1. Bagaimana penerapan pembelajaran PPKn yang di laksanakan oleh guru SMA/SMK swasta Kulon Progo Yogyakarta?

2. Bagaimana Pengembangan model pembelajaran PPKn anti koruspi berbasis lingkungan melalui cooperative learning di SMA/SMK swasta Kulon Progo Yogyakarta?

3. Bagaimana Implementasi model pembelajaran PPKn anti korupsi berbasis lingkungan melalui cooperative learning di SMA/SMK swasta Kulon Progo Yogyakarta?

4. Berapa prosentase keberhasilan pemahaman konsep pembelajaran PPKn anti korupsi berbasis lingkungan melalui cooperative learning di SMA/SMK swasta Kulon Progo Yogyakarta?

5. Berapa prosentase keberhasilan prestasi akademik pada mata pelajaran PPKn anti korupsi berbasis lingkungan melalui cooperative learning di SMA/SMK swasta Kulon Progo Yogyakarta?

Berdasarkan masalah yang dirumuskan, penelitian ini mempunyai tujuan yaitu.

1. Mendeskripsikan penerapan pembelajaran PPKn yang di laksanakan oleh guru SMA swasta Kulon Progo Yogyakarta

2. Mendeskripsikan pengembangan model pembelajaran PPKn anti korupsi berbasis lingkungan melalui cooperative learning di SMA swasta Kulon Progo Yogyakarta.

3. Mendeskripsikan implementasi model pembelajaran PPKn anti korupsi berbasis lingkungan melalui cooperative learning di SMA swasta Kulon Progo Yogyakarta.

4. Menguji dan membandingkan perbedaan pemahaman konsep pada mata pelajaran PPKn anti korupsi berbasis lingkungan melalui cooperative learning di SMA swasta Kulon Progo Yogyakarta.

5. Menguji dan membandingkan prestasi akademik pada mata pelajaran PPKn anti korupsi berbasis lingkungan melalui cooperative learning di SMA swasta Kulon Progo Yogyakarta. 


\section{Landasan Teori}

\section{Pengembangan Model Pembelajaran PPKn}

\section{a. Pengertian Model Pembelajaran}

Keberhasilan pembelajaran sangat dipengaruhi oleh model pembelajaran. Model pembelajaran dapat dipahami sebagai suatu pendekatan, perencanaan atau acuhan yang digunakan sebagai pedoman dalam merencanakan pembelajaran di kelas. Model adalah pola (contoh, acuan, ragam) dari sesuatu yang akan dibuat atau dihasilkan (Departemen $\mathrm{P}$ dan K 1984:75). Selain itu, Simamarta, (1983: ix - xii dalam www.damandiri.or.id) menjelaskan bahwa:

Model adalah abstraksi dari sistem sebenarnya, dalam gambaran yang lebih sederhana serta mempunyai tingkat prosentase yang bersifat menyeluruh, atau model adalah abstraksi dari realitas dengan hanya memusatkan perhatian pada beberapa sifat dari kehidupan sebenarnya.

Uraian di atas dapat diketahui bahwa model pembelajaran merupakan langkah atau prosedur dalam pelaksanaan pembelajaran. setiap model pembelajaran mempunyai keunikan tersendiri.

\section{b. Mata Pelajaran PPKn}

PPKn mempunyai peran penting dalam membentuk perilaku siswa agar selalu taat pada peraturan atau hukum. Berdasarkan Undang-undang Nomor 20 Tahun 2003 tentang Sistem Pendidikan Nasional pasal 37 ayat 1-2 disebutkan bahwa PPKn merupakan mata pelajaran wajib pada pendidikan dasar, menengah, maupun tinggi. PPKn dimaksudkan agar bangsa Indonesia memiliki kesadaran sebagai warga Negara. Sumarsono dkk. (2005:4), menyatakan:

Tujuan utama PPKn adalah untuk menumbuhkan wawasan dan kesadaran berwarganegara, sikap serta perilaku yang cinta tanah air dan bersendikan kebudayaan bangsa, wawasan nusantara, serta ketahanan nasional dalam diri para mahasiswa calon sarjana/ilmuwan warga negara Negara Kesatuan Republik Indonesia yang sedang mengkaji dan akan menguasai iptek dan seni.

Adapun misi atau tanggung jawab Pendidikan Kewarganegaraan menurut Sumarsono dkk. (2005:4), yaitu:

Untuk menumbuhkan wawasan warga negara dalam hal persahabatan, pengertian antar bangsa, perdamaian dunia, kesadaran bela negara, dan sikap serta perilaku yang bersendikan nilai-nilai budaya bangsa, wawasan nusantara dan ketahanan nasional.

Pendidikan Kewarganegaraan yang berhasil akan terwujud sikap, perilaku yang baik dan bertanggung jawab, sehingga bangsa Indonesia khusunya pelajar mempunyai kesadaran hukum yang tinggi. Keberhasilan pembelajaran PPKn sangat dipengaruhi dalam proses 
pembelajaran. maka dari itu penggunaan model dan strategi pembelajaran sangatlah penting untuk mewujudkan tujuan pembelajaran.

\section{Anti Korupsi Berbasis Lingkungan}

\section{Pengertian Pendidikan Anti Korupsi}

Pendidikan anti korupsi adalah:

Usaha sadar untuk memberi pemahaman dan pencegahan terjadinya perbuatan korupsi yang dilakukan melalui pendidikan formal dimadrasah, pendidikan informal pada lingkungan keluarga, dan pendidikan non formal di masyarakat (Keputusan Direktur Jendral Pendidikan Islam, 2013: 8).

Pada umumnya korupsi merupakan perilaku pejabat publik yang menyalahgunakan kekuasaannya untuk kepentingan pribadi sehingga melanggar hukum dan merugikan negara (Samawi dkk., 2013:235). Widjojanto (2013: 19) menyatakan bahwa nilai-nilai anti korupsi meliputi 1) nilai inti antara lain jujur, disiplin, dan tanggung jawab. 2) sikap antara lain adil, berani dan peduli. 3) etos kerja, antara lain kerja keras, sederhana dan mandiri.

Nilai-nilai anti korupsi menurut Kholis (2014 : 23) yaitu sebagaimana dipaparkan dalam tabel 1 berikut :

Tabel 1. Nilai-Nilai Pendidikan Anti Korupsi

\begin{tabular}{|l|l|l|}
\hline & Nilai & Indikator \\
\hline 1. & Jujur & $\begin{array}{l}\text { Selalu berbicara dan berbuat sesuai dengan fakta (konsisten). } \\
\text { Tidak melakukan perbuatan curang. Tidak berbohong. Tidak } \\
\text { mengakui milik orang lain sebagai miliknya }\end{array}$ \\
\hline 2. & Disiplin & $\begin{array}{l}\text { Berkomitmen untuk selalu berperilaku konsisten dan } \\
\text { berpegang teguh pada aturan yang ada dalam semua } \\
\text { kegiatan. }\end{array}$ \\
\hline 3. & Tanggungjawab & $\begin{array}{l}\text { Selalu menyelesaikan pekerjaan atau tugas-tugas secara } \\
\text { tuntas dengan hasil terbaik. }\end{array}$ \\
\hline 4. & Peduli & $\begin{array}{l}\text { Menjaga diri dan lingkungan agar tetap konsisten dengan atur } \\
\text { Selalu berusaha untuk menjadi teladan dalam menegakkan di } \\
\text { dan tanggung jawab bersama. }\end{array}$ \\
\hline
\end{tabular}

Menurut Komisi Pemberantasan Korupsi (KPK) ada Sembilan nilai-nilai luhur (positif) yang membentuk karakter nilai anti korupsi yaitu jujur, disiplin, tanggung jawab, peduli, kerja keras, berani, mandiri, sederhana dan adil (Kementerian Agama RI; 2014 : 6).

Pendidikan anti korupsi pada umumnya dapat di terapkan pada semua mata pelajaran melalui model pembelajaran yang terpusat pada peserta didik. pendidikan anti korupsi dimaksudkan agar peserta didik mempunyai pemahaman dan bisa mencegah terjadinya 
praktik korupsi. Selain itu untuk menanamkan nilai-nilai karakter yang sesuai dengan fungsi dan tujuan pendidikan.

2. Pembelajaran Berbasis Lingkungan

Menurut Senjaya (2008: 99) konsep mengajar sebagai proses mengatur lingkungan, meliputi:

a. mengajar berpusat pada siswa. Mengajar tidak ditentukan oleh guru, akan tetapi sangat ditentukan oleh kebutuhan siswa itu sendiri. Hendak belajar apa siswa, bagaimana cara mempelajarinya, dan kapan dia belajar, bukan guru yang menentukan, namun atas kemauan dan kebutuhan siswa. Peran guru sebagai fasilitator, artinya guru lebih banyak berperan sebagai orang yang membantu siswa belajar. Oleh karena itu kriteria keberhasilan proses pembelajaran dapat diukur dari sejauh mana siswa telah melakukan proses pembelajaran.

b. Siswa sebagai subyek belajar. Konsep pembelajaran berbasis lingkungan, siswa tidak di anggap sebagai organisme yang pasif, yang hanya sebagai penerima informasi. Akan tetapi dipandang sebagai organisme yang aktif, yang memiliki potensi untuk berkembang. Mereka adalah individu yang memiliki kemampuan dan potensi yang harus diakui dan di dorong untuk berkembang.

c. Proses pembelajaran berlangsung dimana saja. Sesuai karakteristik pembelajaran yang berbasis lingkungan, maka pembelajaran tidak dibatasi oleh tempat atau ruang kelas saja. Proses pembelajaran dapat berlangsung dimana saja, tergantung karakteristik materi yang sedang mereka pelajari. Misalnya jika mereka mempelajari permintaan dan penawaran barang maka pasar menjadi tempat belajar siswa. Jika dia hendak mempelajari pendapatan nasional, maka minimum para siswa belajar dari sumbersumber pendapatan keluarga atau masyarakat. Dengan demikian keluarga atau masyarakat itu sendiri menjadi sumber belajar. Pembelajaran seperti ini sering di sebut pembelajaran kontektual.

d. Pembelajaran berorientasi pada pencapaian tujuan. Tujuan pembelajaran bukanlah penguasaan materi pelajaran, akan tetapi proses untuk mengubah tingkah laku siswa sesuai dengan tujuan yang hendak di capai. Oleh karena itu penguasaan materi bukanlah akhir dari proses pembelajaran, tetapi hanya sebagai tujuan untuk membentuk pola perilaku itu sendiri. Untuk itu metode dan strategi yang digunakan tidak hanya ceramah saja, tetapi harus menggunakan berbagai macam metode, sesuai dengan obyek bahasan yang akan mereka pelajari. 
Lingkungan yang kondusif menurut mulyasa dalam Yamin (2007: 96-97) dikembangkan melalui layanan sebagai berikut:

1) Memberikan pilihan bagi peserta didik baik yang lambat maupun yang cepat dalam melakukan tugas pembelajaran. Pilihan dalam pelayanan individual bagi peserta didik, terutama bagi mereka yang lambat belajar akan membangkitkan nafsu dan semangat belajar sehingga membuat mereka betah belajar disekolah.

2) Memberikan pembelajaran remedial bagi peserta didik yang kurang berprestasi, atau berprestasi rendah dalam pembelajaran klasikal, sebagian peserta didik akan sulit untuk mengikuti pembelajaran secara optimal dan menuntut peran ekstra guru untuk memberikan pembelajaran remedial.

3) Mengembangkan organisasi kelas yang efektif, menarik, nyaman, dan aman bagi perkembangan potensi seluruh peserta didik secara optimal. Termasuk dalam hal ini adalah penyediaan bahan pembelajaran yang menarik dan menantang bagi peserta didik, serta pengelolaan kelas yang tepat, efektif, dan efesian.

4) Menciptakan kerja sama saling menghargai baik antar peserta didik maupun dengan guru dan pengelola pembelajaran lain. Hal ini mengandung indikasi bahwa setiap peserta didik memiliki kesempatan yang seluas-luasnya untuk mengemukakan pandangannya tanpa rasa takut mendapatkan sangsi atau dipermalukan.

5) Melibatkan peserta didik dalam proses perencanaan pembelajaran. dalam hal ini guru harus mampu memposisikan diri sebagai pembimbing. Guru perlu melibatkan peserta didik dalam proses perencanaan pembelajaran, agar mereka merasa bertanggung jawab terhadap pembelajaran yang dilaksanakan.

6) Mengembangkan proses pembelajaran sebagai tanggung jawab bersama antara peserta didik dan guru, sehingga guru lebih banyak bertindak sebagai fasilitator, dan sebagai sumber belajar.

Pembelajaran berbasis lingkungan mempunyai beberapa karakteristik yaitu: 1) pembelajaran dapat berlangsung di mana saja, 2) Peserta didik dapat menentukan topik materi yang akan dipelajari. Peserta didik dilibatkan dalam perencanaan awal sampai akhir pembelajaran, 3) Menciptakan pembelajaran yang menyenangkan, dan 4) terciptanya tujuan pembelajaran. pembelajaran berbasis lingkungan dapat memperkaya peserta didik dalam memperoleh ilmu pengetahuan yang dipelajari. Peserta didik dapat mempelajari materi dari berbagai sumber belajar. Pendidikan anti korupsi berbasis lingkungan merupakan model pembelajaran yang menggembirakan dengan mengedepankan nilai-nilai karakter, 
kemampuan dan potensi masing-masing peserta didik dengan lingkungan sebagai media atau sumber belajar.

\section{Cooperative learning}

Pembelajaran kooperatif menurut Sanjaya, (2014:242) adalah:

Model pembelajaran dengan menggunakan sistem pengelompokan/tim kecil, yaitu antara empat sampai enam orang yang mempunyai latar belakang kemampuan akademik, jenis kelamin, ras, atau suku yang berbeda.

Selain itu Daryanto (2013:412) menyatakan bahwa pembelajaran kooperatif merupakan model pembelajaran yang mengutamakan kelompok-kelompok. Dapat diketahui bahwa pembelajaran kooperatif merupakan model pembelajaran dimana peserta didik bekerja sama membentuk kelompok-kelompok kecil yang anggotanya hiterogen. Beberapa tipe model pembelajaran kooperatif yang dikemukakan oleh beberapa ahli meliputi: jigsaw, number heads together, student teams achiement division, dan team assited individualization atau team accelerated instruction. Daryanto: 2013: 415-418). Sedangkan prinsip-prinsip pembelajaran kooperatif antara lain: ketergantungan positif, tanggung jawab perseorangan, interaksi tatap muka, partisipasi dan komunikasi (Sanjaya: 2014: 246-247).

Pengembangan model pembelajaran PPKn anti korupsi berbasis lingkungan melalui cooperative learning merupakan pengembangan pembelajaran yang terpusat pada peserta didik sesuai dengan nilai-nilai karakter agar pembelajaran lebih aktif, inovatif, kreatif, efesien dan menyenangkan. Tujuan pembelajaran dapat tercapai dengan maksimal apabila konsep PAIKEM tercapai dengan baik.

\section{Penelitian Terdahulu}

Banyak peneliti yang melakukan penelitian berkaitan tentang model pengembangan pembelajaran, pengembangan kurikulum, dan pengembangan materi ajar. Model pengembangan tersebut sangatlah beragam. Penelitian ini berawal dari penelitian sebelumnya yang berkaitan tentang pengembangan pendidikan dalam pembelajaran. Hasil penelitian Sarjono dkk. (2014) tentang menegement development of economics learning that is based on environment with innovative approach at SMA Muhammadiyah Surakarta, dapat diketahui bahwa Implementation of economics learning model that is based on environment with inovative learning approach at SMA Muhammadiyah Surakarta has given positive effect and contribution on increasing student' concept understanding of Economics lesson, so that, to be efective to have been conducted by teachers. there is an increasing on students' academic achievement through the implementation of economics learning model that is based on environment with inovative learning approach at SMA Muhammadiyah Surakarta than before (Asia Pasific Journal of Research Vol: I Issue xiv, June 2014). Selain 
itu Chi Huang dkk. (2011) tentang cooperative weblog learning in higher education: its facilitating effects on social interaction, time lag, and cognitive load, menyatakan bahwa Weblogs with Jigsaw cooperative learning activities, promoted better social interactions than those found in the comparison group. RSS feeds and keyword searches made important contributions to cooperative learning, more than had been previously identified in the literature. These two components were found to alleviate cognitive overload and the consequences of time lag. Consequently, this study provides new insights into the role of weblogging in higher education (Educational Technology \& Society, 14 :1).

Hasil penelitian Kupczynski dkk. (2012) tentang cooperative learning in distance learning: a mixed methods study, membuktikan bahwa The qualitative data revealed that students in the cooperative learning groups found more learning benefits than the Traditional group. The study will benefit instructors and students in distance learning to improve teaching and learning practices in a virtual classroom (international journal of instruction, July 2012 vol 5). Kemudian Samawi dkk., (2013) tentang model pembelajaran anti korupsi untuk mengembangkan karakter bangsa yang bersih dari KKN dan implikasinya dalam pendidikan inklusi. hasil penelitian dapat disimpulkan bahwa model pembelajaran anti korupsi dikemas dalam bentuk rasional akademik melalui problem solving dan investigasi. Mahasiswa dikelompokkan dengan mengintegrasikan mahasiswa regular dan berkebutuhan khusus. Perkuliahan menjadi hidup, aktif, kritis, dan interaktif. Kesimpulannya model pembelajaran anti korupsi dapat mengembangkan karakter bangsa yang bersih dari KKN (Journal FPPsi UM 2013).

Berbagai penelitian tersebut dapat diketahui bahwa pembelajaran anti korupsi, berbasis lingkungan, dan cooperative learning dapat berpengaruh terhadap keberhasilan belajar dan pengembangan karakter. Hasilnya menunjukkan bahwa dengan berbagai model pembelajaran tersebut, hasil belajar, dan prestasi siswa meningkat. Namun, peneliti akan mengembangkan hasil dari penelitian sebelumnya terkait pembelajaran anti korupsi berbasis lingkungan melalui cooperative learning. Hal tersebut dimaksudkan agar tujuan pembelajaran dapat tercapai lebih baik lagi, yang mengedepankan pembelajaran terpusat pada peserta didik dengan keadaan dan suasana aktif, kreatif, inovatif, efesien dan menyenangkan serta pengembangan nilai-nilai karakter.

Berdasarkan kajian teoritis sebagaimana dipaparkan di atas, maka penelitian ini perlu menganjurkan anggapan dasar atau kerangka pemikiran meliputi:

1. Pengembangan model pembelajaran merupakan melakukan perubahan yang lebih inovatif model pembelajaran, dimana model pembelajaran merupakan langkah atau 
prosedur dalam pelaksanaan pembelajaran. setiap model pembelajaran mempunyai keunikan tersendiri.

2. Model pembelajaran PPKn anti korupsi berbasis lingkungan adalah model pembelajaran dengan materi-materi tentang wawasan kebangsaan atau pengetahuan sosial dengan konsep pembelajaran yang disukai peserta didik dimana lingkungan di jadikan sumber pembelajaran, serta pengembangan nilai-nilai karakter.

3. Cooperative learning merupakan pembelajaran dimana peserta didik dibagi menjadi beberapa kelompok yang anggotanya hiterogen. Setiap kelompok dapat bekerja sama untuk memahami materi dengan baik.

\section{Metode Penelitian}

\section{A. Jenis Penelitian}

Jenis penelitian ini adalah research and development dengan pendekatan eksperimen. Hal tersebut didasarkan pada kenyataan bahwa metode eksperimen merupakan metode yang tepat dan akurat untuk memenuhi fungsi ilmu yaitu menjelaskan, memprediksi, dan mengontrol. Metode eksperimen mempunyai struktur yang paling ketat dan transparan.

\section{B. Model Pengembangan}

Model penelitian pengembangan ini menggunakan model yang digunakan secara singkat, sebagai pengembangan model. Adapun model pengembangan dalam penelitian ini sebagaimana dipaparkan dalam gambar 1 berikut:

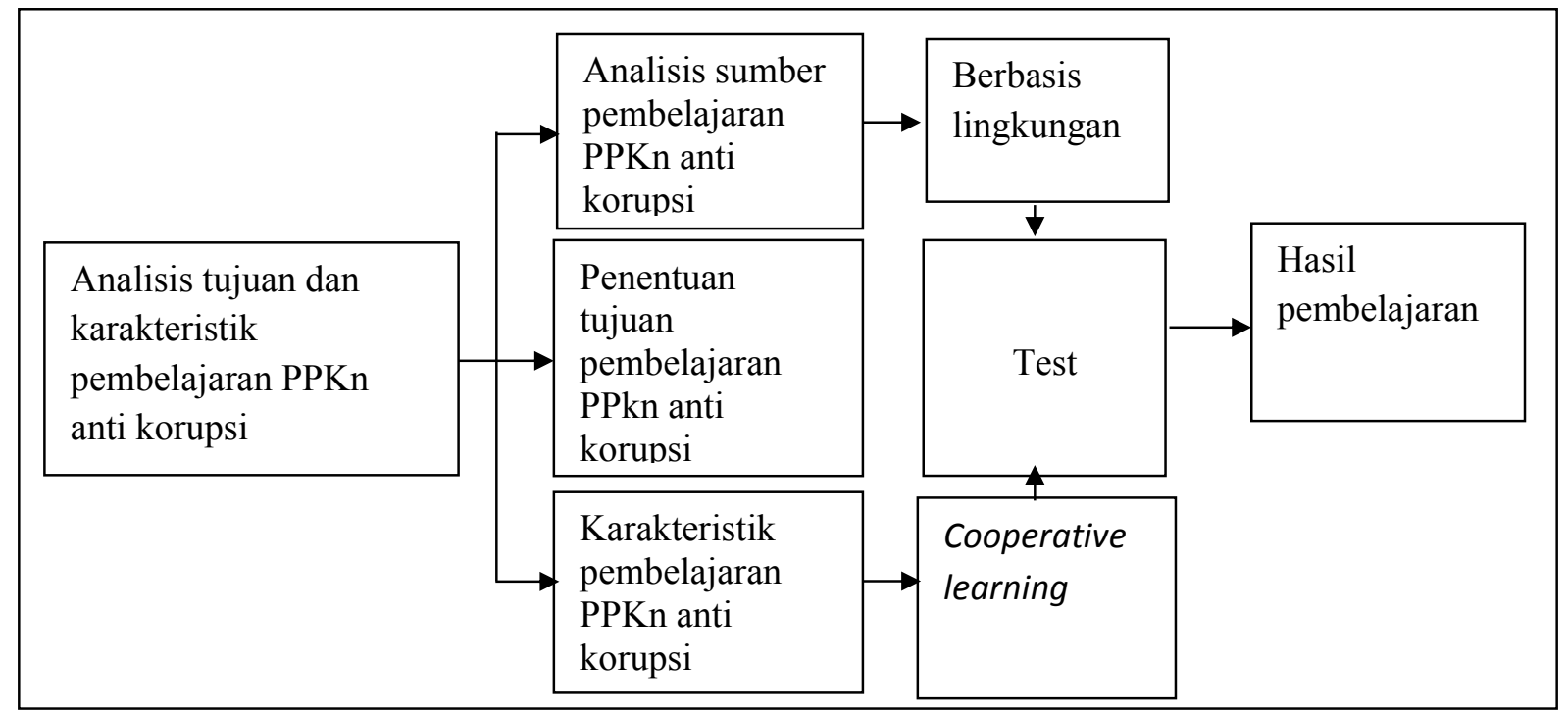

Gambar 1. Model Pengembangan Pembelajaran PPKn anti korupsi Berbasis Lingkungan melalui Cooperative learning 


\section{Prosedur Pengembangan}

1.Research and information collecting (penelitian dan pengumpulan data).

Melakukan penelitian pendahuluan untuk mengumpulkan informasi

Adapun langkah-langkah modifikasinya menurut Sutama (2011: 195) sebagai berikut:

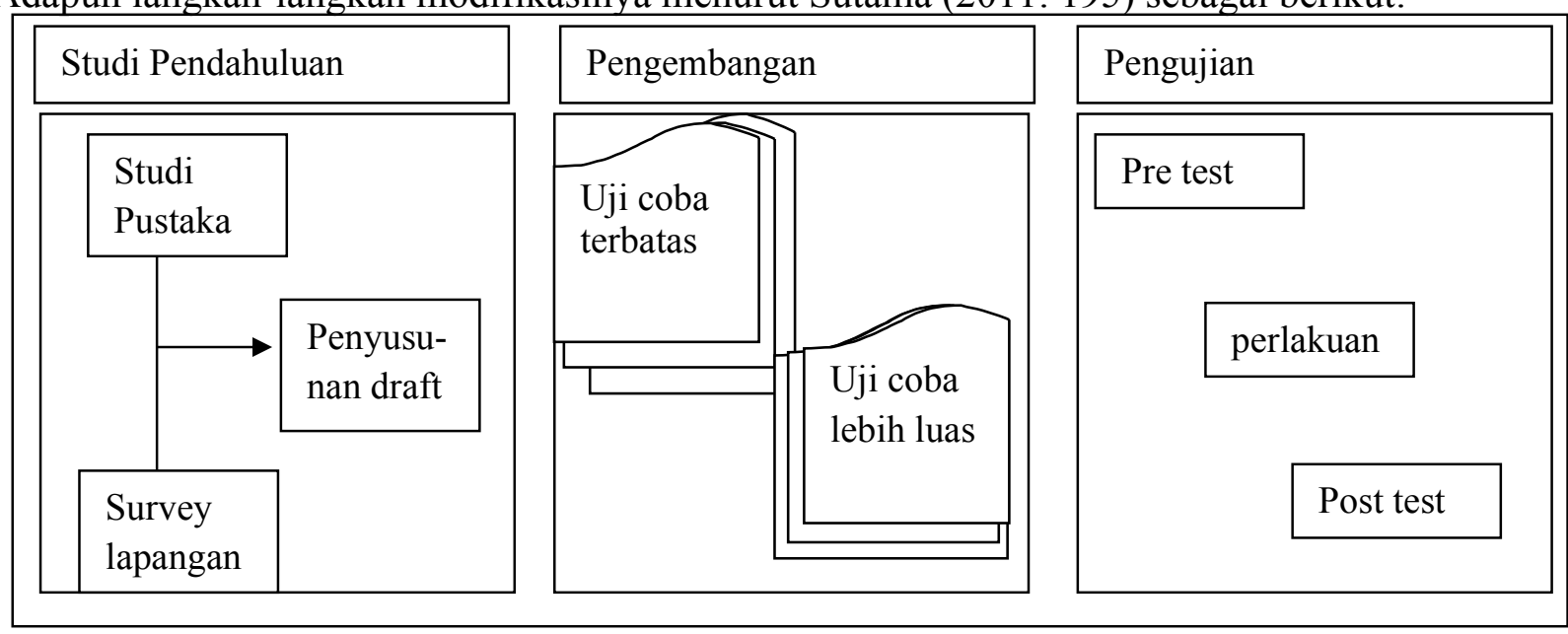

Gambar 2. Langkah-langkah modifikasi pengembangan

\section{Pengembangan Model}

a. desain pengembangan

Rancangan atau desain penelitian dan pengembangan (Sugiyono; 2008:407) yaitu:

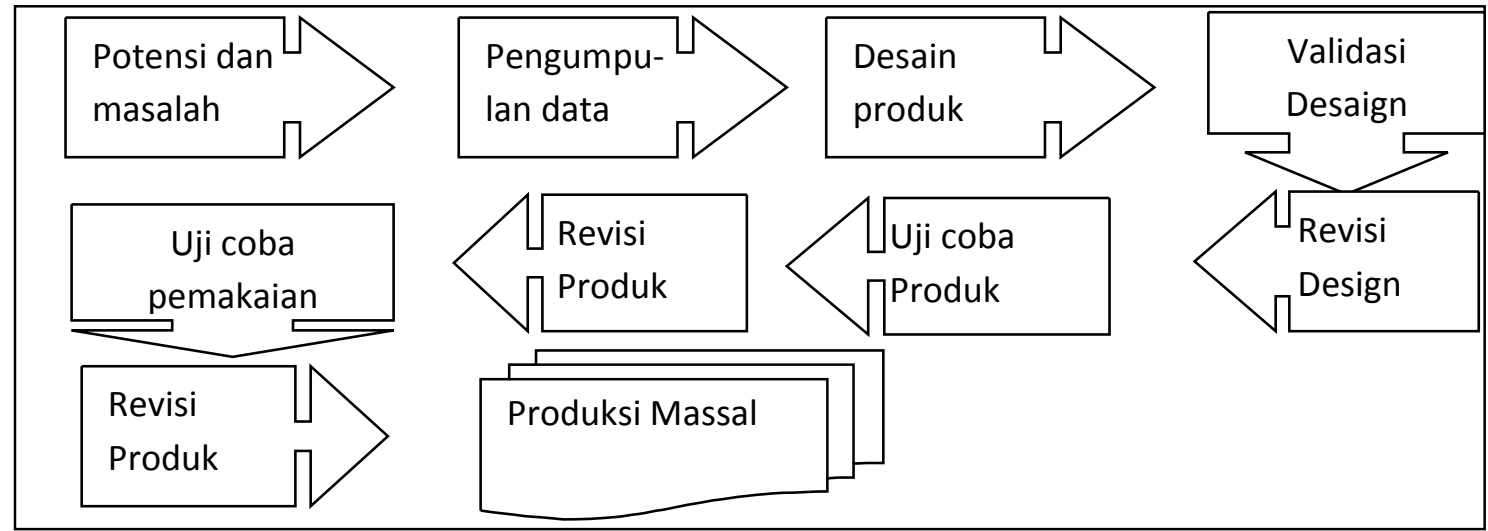

Gambar 3. Rancangan atau desain penelitian

b. subjek pengembangan

Adapun subjek pengembangan dalam penelitian ini adalah subyek penelitian ini adalah para siswa dan guru SMA swasta Kulon Progo Yogyakarta.

c jenis data

Dalam uji coba, data digunakan sebagai dasar untuk menentukan keefektifan, efisiensi, dan daya tarik model yang dihasilkan. Jenis data yang akan dikumpulkan harus disesuaikan dengan informasi yang dibutuhkan tentang model yang dikembangkan dan tujuan pembelajaran yang ingin dicapai. 
d. Teknik pengumpulan data

Dalam pengumpulan data dapat digunakan berbagai teknik pengumpulan data atau pengukuran yang disesuaikan dengan karakteristik data yang akan dikumpulkan dan responden penelitian.

e. teknik analisis data

Teknik analisis data yang digunakan disesuaikan dengan jenis data dikumpulkan, yaitu terkait pengembangan model pembelajaran PPKn anti korupsi berbasis lingkungan melalui cooperative learning di SMA swasta Kulon Progo Yogyakarta.

f. keabsahan data

Dalam penelitian ini keabsahan data kualitatif a) observasi secara terus menerus, dan b) trianggulasi sumber.

\section{B. Hasil Pembahasan}

1. Penerapan pembelajaran PPKn yang di laksanakan oleh guru SMA/SMK swasta Kulon Progo Yogyakarta.

Guru merupakan peran utama dalam proses pembelajaran dikelas. Berhasil tidaknya proses pembelajaran sangatlah tergantung pada guru dalam penyampaian materi. Di beberapa SMA atau SMK di Kulon Progo dalam penyampaian materi PPKn oleh guru dapat diketahui antara lain 1) Persiapan guru masih kurang sebelum penerapan materi. Hal tersebut dapat dilihat antara lain kesiapan membuat perangkat pembelajaran, persiapan diri guru masih kurang. 2) guru belum sepenuhnya mengimplementasikan atau menanamkan nilai-nilai anti korupsi pada mata pelajaran PPKn. 3) pembelajaran kebanyakan di laksanakan di dalam kelas, sehingga lama kelamaan bisa jadi siswa akan bosan. 4) model yang sering di pakai oleh guru adalah ceramah, diskusi dan presentasi saja. 5) guru belum mengembangkan model dengan maksimal. dan 6) guru jarang melakukan display ruang kelas ketika pelaksanaan pebelajaran.

Setiap siswa dapat dikatakan pembelajar yang unik, karena mempunyai keinginan yang berbeda-beda. Dari keunikan siswa tersebut seorang guru haruslah berhati-hati dalam menyampaikan materi di kelas. Jangan sampai siswa tidak nyaman dalam proses pembelajaran. Namun, tidak kesemuanya guru berfikir demikian sehingga akan berakibat ketidaknyamanan siswa dalam proses pembelajaran. Hasil temuan lapangan selama pelaksanaan pembelajaran dapat di ketahui bahwa: 1) masih banyak siswa yang malas, jenuh selama proses pembelajaran. 2) Sebagian siswa bermain hp membuka sosial media dan lain sebagainya. 3) Siswa masih ramai atau berbuat gaduh. 4) Siswa ada yang tertidur di kelas di saat proses pembelajaran. Sarana dan prasarana merupakan hal penting dalam 
menunjang proses pembelajaran. dapat di ketahui bahwa sarana dan prasarana masih kurang. Misalnya buku paket/bahan ajar, dan media-media yang lain yang menunjang pelaksanaan pembelajaran berlangsung.

2. Pengembangan model pembelajaran PPKn anti koruspi berbasis lingkungan melalui cooperative learning di SMA/SMK swasta Kulon Progo Yogyakarta.

Peneliti mengembangkan pembelajaran PPKn Anti Korupsi berbasis lingkunngan.

Hal tersebut dimaksudkan agar pembelajaran berjalan dengan baik sesuai dengan tujuan pembelajaran.

1) Pengembangan Draf

Pada tahap studi pendahuluan telah dilakukan studi pustaka, studi lapangan dan di buat draf awal serta desain model pengembangan pembelajaran PPKn Anti Korupsi berbasis lingkungan. Selanjutnya akan dilanjutkan penerapan ujicoba draf dan desain awal. Penerapan model ini digunakan dalam pengembangan draf desain model pembelajaran melalui uji coba model lapangan, baik uji coba dalam skala terbatas maupun skala lebih luas. Penerapan model pembelajaran ini memiliki langkah-langkah pembelajaran sebagai berikut:

\section{Tahap pertama: Pendahuluan}

Guru memberi salam kepada siswa, menanyakan keadaan siswa, dan memfokuskan siswa untuk siap belajar melalui kegiatan ice breaking dan motivasi siswa (nilai anti korupsi: jujur, disiplin, tanggung jawab, peduli).

\section{Tahap kedua: Analogi langsung rencana isi}

Guru memperkenalkan standar kompetensi, kompetensi dasar, indikator, tujuan pembelajaran dan prosedur pembelajaran (nilai anti korupsi: jujur, disiplin, tanggung jawab, peduli).

\section{Tahap ketiga: Penerapan}

Guru, peneliti dan siswa menerapkan pembelajaran PPKn Anti Korupsi berbasis lingkungan dengan strategi cooperative learning (nilai anti korupsi: jujur, disiplin, tanggung jawab, peduli)

\section{Tahap keempat: Evaluasi}

1. Evaluasi proses, dilaksanakan selama proses pembelajaran berlangsung.

2. Formatif dan sumantif

3. Kinerja

Gambar 4 Langkah awal pembelajaran Anti Korupsi berbasis lingkungan 
Adapun langkah-langkah pengembangan model adalah sebagai berikut:

\section{Tahap pertama: Pendahuluan}

Guru memberi salam kepada siswa, menanyakan keadaan siswa, dan memfokuskan siswa untuk siap belajar melalui kegiatan ice breaking dan motivasi siswa (nilai anti korupsi: jujur, disiplin, tanggung jawab, peduli).

\section{Tahap kedua: Inti Pembelajaran}

1. Penyajian secara umum meliputi: tujuan pembelajaran, penguatan pemahaman siswa, penyampaian tahapan pembelajaran dan display ruang kelas.

2. Pengajuan, membandingkan, dan menjelaskan analogi melipuri: pengajuan analogi langsung, meminta siswa membandingkan kaitan antara aspek-aspek materi yang dibahas dengan aspek yang ada dalam objek atau kegiatan yang dianalogikan, dan meminta siswa menjelaskan hasil yang dianalogikan.

3. Analogi tim meliputi meminta dan mendorong kelompok siswa mengajukan analogi, meminta kelompok siswa mendiskusikan tema dan atau topik materi, meminta kelompok siswa merangkum hasil diskusi.

4. Pengajuan analogi baru, meliputi meminta siswa melakukan pengajuan analogi baru terhadap materi yang di bahas, mendorong siswa agar bisa melakukan analogi baru, meminta siswa menjelaskan persamaan dan perbedaan antara aspek-aspek yang ada pada materi yang sedang di bahas dengan objek atau kegiatan yang dianalogikan. (nilai anti korupsi: jujur, disiplin, tanggung jawab, peduli).

\section{Tahap ketiga: Penutup}

Guru melakukan konfirmasi, kesimpulan dan tindak lanjut pertemuan berikutnya (nilai anti korupsi: jujur, disiplin, tanggung jawab, peduli).

Gambar 5. Langkah pengembangan pembelajaran Anti Korupsi berbasis lingkungan

\section{Implementasi model pembelajaran PPKn anti korupsi berbasis lingkungan} melalui cooperative learning di SMA/SMK swasta Kulon Progo Yogyakarta.

Desain model pembelajaran kemudian diuji cobakan di kelas secara siklis. Dilakukan pengamatan terkait ujicoba tersebut sehingga dapat diketahui kelemahan dari ujicoba terbatas. Hasil pengamatan dipakai sebagai evaluasi untuk pelaksanaan ujicoba berikutnya. Aspek yang dinilai dalam uji coba pertama, meliputi kemampuan, kinerja guru, aktivitas dan prestasi siswa.

\section{Ujicoba terbatas}

Uji coba terbatas bertujuan untuk memperoleh deskripsi latar penerapan atau kelayakan desain model pembelajaran berbasis lingkungan yang dikembangkan. Hasil ujicoba terbatas ini dipakai sebagai bahan untuk melakukan revisi dan evaluasi terhadap 
desain model pembelajaran yang sedang dikembangkan. Aspek yang dinilai dalam ujicoba model, yaitu kemampuan, kinerja pengajar, kemampuan dan aktivitas siswa.

\section{Kemampuan dan kinerja pengajar}

Model pembelajaran anti korupsi berbasis lingkungan melalui cooperative learning merupakan model pembelajaran yang efektif dalam rangka pembentukan konsep nilai-nilai anti korupsi siswa materi sistem hukum dan peradilan nasional. Membutuhkan kecakapan, ketrampilan dan kerjasama siswa sejak dari perencanaan hingga setelah selesai kegiatan pembelajaran. Berdasarkan hasil ujicoba dalam skala terbatas diperoleh beberapa temuan:

\section{Kemampuan pengajar dalam membuat desain pembelajaran.}

Diadakannya diskusi antara pengajar dan peneliti terkait materi yang dipelajari. Selanjutnya, membuat desain pembelajaran PPKn anti korupsi berbasis lingkungan melalui cooperative learning. Materi yang dipelajari adalah sistem hukum dan peradilan nasional. Kemampuan pengajar dalam membuat desain pembelajaran sudah baik. Pengajar mencari berbagai referensi diberbagai sumber terlebih dahulu yang meliputi lingkungan sekitar, masyarakat, buku, internet, dan surat kabar. Dalam membuat desain pembelajaran pengajar bekerjasama dengan peneliti.

\section{Kemampuan pengajar dalam melaksanakan kegiatan pembelajaran.}

Kegiatan pembelajaran dibagi menjadi 3 tahap, yaitu tahap pendahuluan, tahapan inti, dan penutup. Tahapan tersebut akan diwujudkan dalam bentuk beragam kegiatan sesuai dengan model pembelajaran yang dipakai pengajar

Tahap pertama adalah pendahuluan. Kegiatan pendahuluan belum dapat terlaksana secara maksimal. Penyampaian pada tahap pertama ini kurang menarik. Pengajar belum menguasainya dengan baik. Selanjutnya tahap kedua adalah inti pembelajaran. pengajar belum menyampaikan tujuan pembelajaran khusus. kegiatan diskusi belum berjalan secara maksimal. banyak peserta didik yang asyik mengobrol membicarakan hal-hal lain di saat kegiatan diskusi. Selain itu dalam penyampaian materi pengajar masih menjelaskan materi secara umum. Pada tahap ketiga adalah tahapan penutup. pada tahapan ini terdiri dari konfirmasi, kesimpulan dan tindak lanjut pertemuan berikutnya. Pengajar sudah cukup baik dalam menerapkan tahapan ketiga ini.

Terdapat beberapa kelemahan pada ujicoba model terbatas. Kelemahan tersebut dicoba diperbaiki dengan diskusi baik guru, peneliti maupun siswa. Berdasarkan hasil ujicoba terbatas dapat disimpulkan bahwa kemampuan dan kinerja pengajar yang bisa ditampilkan adalah sebagai berikut. 


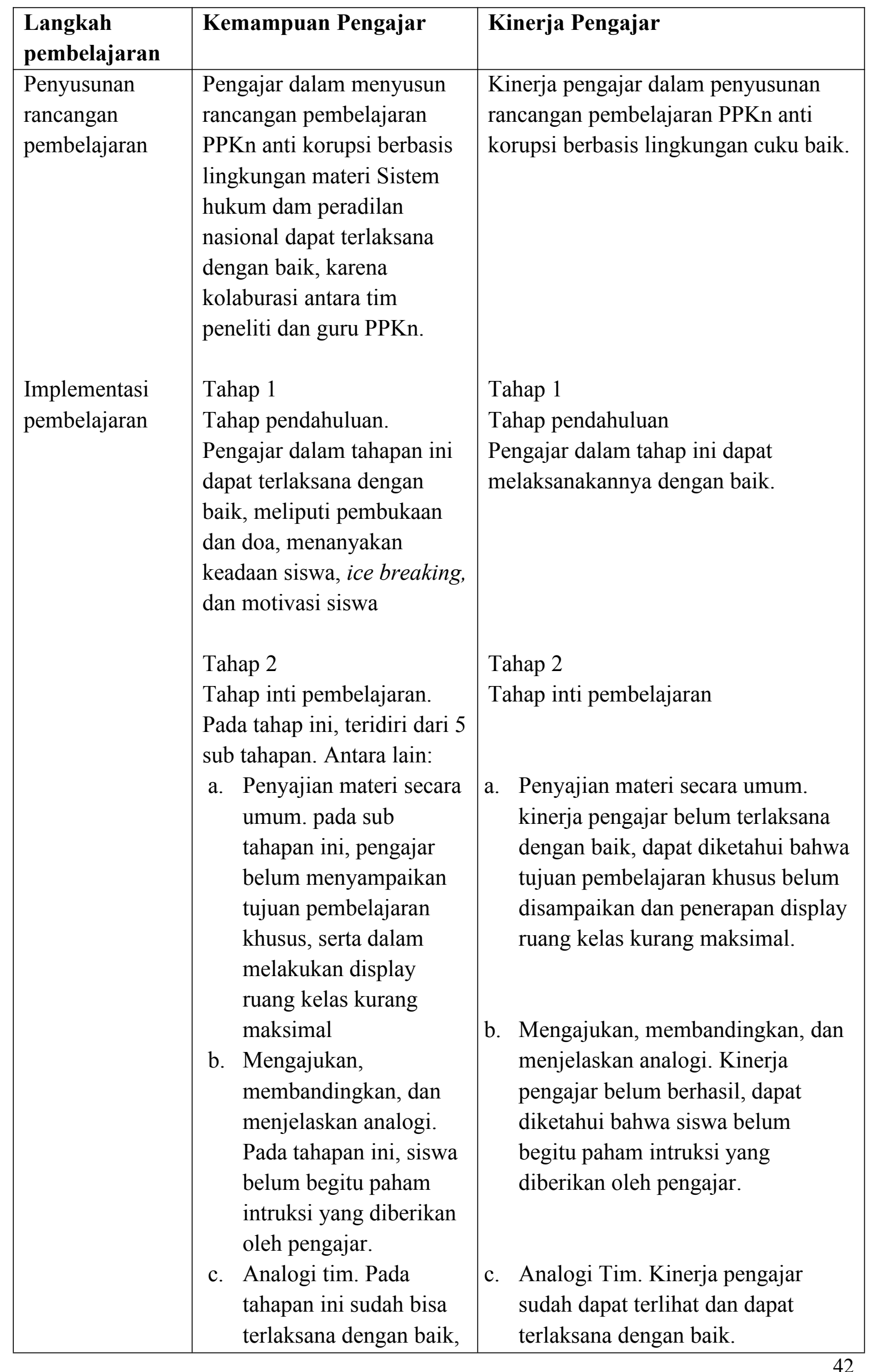




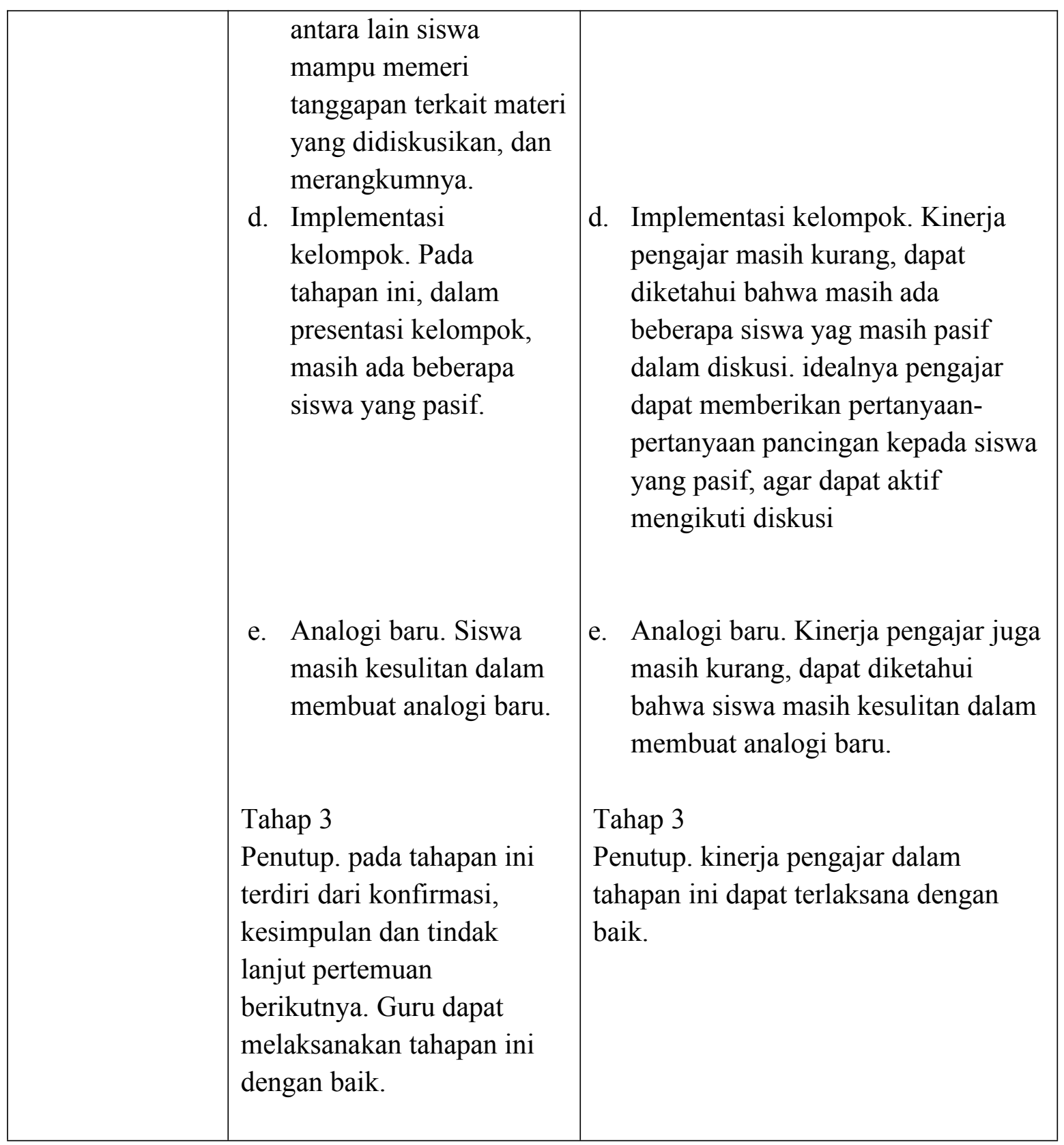

Gambar 6. Kemampuan dan kinerja pengajar dalam ujicoba terbatas

Meskipun masih ada beberapa kekurangan dalam ujicoba model terbatas, namun hasil penerapan ujicoba model terbatas tersebut, sudah menunjukkan peningkatan perubahan perilaku. Hal tersebut dapat dilihat dari analisis nilai awal yang diambil dari nilai ulangan harian yang dilaksanakan oleh pengajar PPKn pada kelas X teknik kendaraan -2 SMK Maaraif 1 Wates Kulonprogo Yogyakarta. Ujicoba model terbatas hanya dilakukan satu kali dan hanya melibatkan 1 kelas. hasil ujicoba model tersebut dapat diketahui bahwa terdapat 28 siswa yang nilanya tuntas dan 4 siswa yang nilainya belum tuntas. Adapaun standar ketuntasan minimalnya adalah 75. Dapat diketahui bahwa hasil ujicoba tersebut terdapat peningkatan pemahaman konsep dan prestasi akademik siswa. 


\section{Tahap uji coba lebih luas}

Beberapa kelemahan dalam penerapan ujicoba model terbatas, kemudian tim peneliti bersama guru merevisi kelemahan-kelemahan yang ada. terutama yang berkaitan dengan penerapan model. pengajar lebih mendalami secara detail materi dan model yang akan diterapkan pada tahap ujicoba lebih luas. Langkah selanjutnya adalah tim peneliti dan tim guru PPKn melakukan penerapan ujicoba lebih luas pada kelas X teknik komputer dan jaringan -1 SMK Maarif 1 Wates Kulon Progo Yogyakarta,

Setelah penerapan ujicoba lebih luas terlaksana, maka dapat diketahui bahwa kemampuan dan kinerja pengajar jauh lebih baik dibanding penerapan pada ujicoba terbatas. Pengajar dalam penerapan model pembelajaran mulai tahapan pertama sampai dengan tahapan terakhir dapat terlaksana dengan baik. selanjutnya aspek yang dapat di ukur untuk menilai implementasi dalam setiap ujicoba model, yaitu pemahaman konsep siswa terhadap materi pembelajaran yang dapat diamati dari jumlah siswa yang mencapai jumlah nilai kriteria ketuntasan minimal dan peningkatan prestasi akademik siswa.

Dapat diketahui bahwa, dari jumlah siswa yaitu 30 siswa sebelum uji coba, terdapat 12 siswa yang tidak lulus sesuai standar kriteria ketuntasan minimal.kemudian setelah dilakukan uji coba terdapat peningkatan baik pemahaman konsep dan prestasi akademik siswa. siswa yang tidak lulus KKM berjumlah 1 siswa.

Ujicoba lebih luas yang kedua adalah kelas X SMA Muhammadiyah Wates Kulon Progo Yogyakarta. bahwa uji coba lebih luas yang kedua adalah pada kelas X SMA Muhammadiyah Wates Kulon Progo Yogyakarta. Hasilnya dapat diketahui bahwa jumlah siswa keseluruhan adalah 17 siswa. sebelum ujicoba model, jumlah siswa yang belum tuntas dalam mengikuti ulangan mata pelajaran PPKn adalah 5 siswa. sedangkan jumlah siswa yang sudah tuntas adalah 12 siswa. Setelah uji coba model dapat diketahui bahwa pemahaman konsep dan prestasi akademik siswa meningkat. Dari jumlah keseluruhan siswa adalah 17 siswa. Nilai semua siswa sudah memenuhi kreteria ketuntasan minimal.

Adapun Model pembelajaran PPKn anti korupsi berbasis lingkungan melalui cooperative learning sebagaimana di paparkan dalam gambar berikut.

\section{Tahap Pertama: Pendahuluan}

1. Pembukaan dan berdoa (Niali anti korupsi: peduli, tanggungg jawab, disiplin).

2. Menanyakan keadaan siswa (nilai anti korupsi: Peduli, tanggung jawab).

3. Ice Breaking (nilai anti korupsi: Peduli, tanggung jawab).

4. Sugesthi/motivasi siswa (nilai anti korupsi: peduli, tanggung jawab).

Tahap kedua: Inti Pembelajaran

A. Penyajian materi secara umum 
1. Menyatakan tujuan pembelajaran khusus ( nilai anti korupsi: Peduli).

2. Menguatkan pemahaman siswa (nilai anti korupsi: Peduli).

3. Menyampaikan tahapan-tahapan pembelajaran (nilai anti korupsi: Peduli, jujur).

4. Display ruang kelas (nilai anti korupsi: tanggung jawab, disiplin, peduli)

B. Mengajukan, membandingkan, dan menjelaskan analogi

1. Mengajukan analogi langsung, meminta siswa mendiskripsikan sesuatu yang dianalogikan, mendorong siswa untuk berani mengemukakan pendapat (nilai anti korupsi: jujur, disiplin, tanggung jawab).

2. Meminta siswa membandingkan kaitan antara aspek-aspek dalam materi yang sedang dibahas dengan aspek yang ada dalam obyek atau kegiatan yang dianalogikan (nilai anti korupsi: jujur, tanggung jawab, peduli).

3. Meminta siswa menjelaskan hasil yang dianalogikan dan merangkumnya (nilai anti korupsi: tanggung jawab, disiplin).

C. Analogi Tim

1. Meminta dan mendorong kelompok siswa mengajukan analogi (nilai anti korupsi: jujur, disiplin, tanggung jawab).

2. Meminta kelompok siswa mendiskusikan tema dan atau topik materi (nilai anti korupsi: jujur, disiplin, tanggung jawab, peduli).

3. Meminta kelompok siswa merangkum hasil diskusi (nilai anti korupsi: peduli, jujur, tanggung jawab).

D. Implementasi Kelompok

1. Meminta kelompok siswa mempresentasikan materi yang baru saja dibahas, selanjutnya kelompok lain menanggapai materi yang dipresentasikan, dan mendiskusikan bersama apabila ada materi yang belum dipahami, hal tersebut dilakukan secara bergantian (nilai anti korupsi: tanggung jawab, peduli).

2. Merangkum hasil diskusi siswa perkelompok (nilai anti korupsi: tanggung jawab).

E. Mengajukan analogi baru

1. Meminta siswa mengajukan analogi baru terhadap materi yang yang sedang dibahas (nilai anti korupsi: jujur, disiplin).

2. Mendorong siswa agar bisa membuat analogi baru (nilai anti korupsi: tanggung jawab).

3. Meminta siswa menjelaskan persamaan dan perbedaan antara aspek-aspek yang ada dalam materi yang sedang dibahas dengan obyek atau kegiatan yang dianalogikan (nilai anti korupsi peduli, tanggung jawab).

\section{Tahap ke tiga: Penutup}

1. Konfirmasi (nilai anti korupsi: jujur, disiplin, tanggung jawab).

2. Kesimpulan (nilai anti korupsi: tanggung jawab, peduli, jujur, disiplin).

3. Tindak lanjut pertemuan berikutnya (nilai anti korupsi: peduli, tanggung jawab).

Gambar 7. Model Pembelajaran PPKn Anti Korupsi Berbasis Lingkungan Melalui Cooperative Learning 
4. Persentase keberhasilan pemahaman konsep dan prestasi akademik pada mata pelajaran PPKn anti korupsi berbasis lingkungan melalui cooperative learning di SMA/SMK swasta Kulon Progo Yogyakarta

Persentase keberhasilan pemahaman konsep dan prestasi akademik pembelajaran PPKn anti korupsi berbasis lingkungan melalui cooperative learning di SMA/SMK swasta Kulon Progo Yogyakarta sebelum uji coba sebagaimana di paparkan dalam tabel di bawah ini.

\begin{tabular}{|c|c|c|c|c|c|c|c|c|c|}
\hline \multirow[b]{2}{*}{ No } & \multirow[b]{2}{*}{ Aspek } & \multicolumn{8}{|c|}{ Sebelum Uji Coba } \\
\hline & & $\begin{array}{l}\text { X TKR } 2 \\
\text { SMK } \\
\text { Maarif } 1 \\
32 \text { siswa }\end{array}$ & $\begin{array}{l}\text { X TKJ } 1 \\
\text { SMK } \\
\text { Maarif } 1 \\
30 \text { siswa }\end{array}$ & $\begin{array}{l}\text { X SMA } \\
\text { Muh } \\
17 \text { siswa }\end{array}$ & $\begin{array}{l}\text { X AP } \\
\text { SMK } \\
\text { PGRI } \\
17 \text { siswa }\end{array}$ & $\begin{array}{l}\text { X AK } \\
\text { SMK } \\
\text { PGRI } \\
9 \text { siswa }\end{array}$ & $\begin{array}{l}\mathrm{X} \text { TSM } \\
\text { SMK } \\
\text { Maarif } 3 \\
38 \text { siswa }\end{array}$ & $\begin{array}{l}\text { X TKR } \\
\text { SMK } \\
\text { Maarif } 3 \\
34 \text { siswa }\end{array}$ & $\begin{array}{l}\text { X SMA } \\
\text { Bokpri } \\
4 \text { siswa }\end{array}$ \\
\hline 1 & $\begin{array}{l}\text { Pemahaman } \\
\text { Konsep }\end{array}$ & 15 & 18 & 12 & 11 & 6 & 21 & 22 & 2 \\
\hline 2 & $\begin{array}{l}\text { Persentase } \\
\text { Keberhasila } \\
\text { Pemahaman } \\
\text { Konsep }\end{array}$ & $48 \%$ & $60 \%$ & $71 \%$ & $65 \%$ & $67 \%$ & $55 \%$ & $65 \%$ & $50 \%$ \\
\hline 3 & $\begin{array}{l}\text { Prestasi } \\
\text { akademik } \\
\text { Rata-Rata } \\
\text { Kelas } \\
\end{array}$ & 74 & 59 & 78 & 74 & 74 & 70 & 75 & 71 \\
\hline 4 & $\begin{array}{l}\text { Persentase } \\
\text { Prestasi } \\
\text { Akademik } \\
\text { Rata-Rata } \\
\text { Kelas }\end{array}$ & $74 \%$ & $59 \%$ & $78 \%$ & $74 \%$ & $74 \%$ & $70 \%$ & $75 \%$ & $71 \%$ \\
\hline
\end{tabular}

Tabel 2. Hasil Sebelum Uji Coba Model Pembelajaran PPKn Anti Korupsi Berbasis Lingkungan Melalui Cooperative Learning

Adapun hasil setelah uji coba model sebagaimana dipaparkan dalam tabel berikut.

\begin{tabular}{|c|c|c|c|c|c|c|c|c|c|}
\hline \multirow[b]{2}{*}{ No } & \multirow[b]{2}{*}{ Aspek } & $\begin{array}{l}\text { Uji Coba } \\
\text { Terbatas }\end{array}$ & \multicolumn{2}{|c|}{$\begin{array}{c}\text { Uji Coba Lebih } \\
\text { Luas } \\
\end{array}$} & \multicolumn{5}{|c|}{ Uji Validasi } \\
\hline & & $\begin{array}{l}\text { X TKR } 2 \\
\text { SMK } \\
\text { Maarif } 1 \\
32 \text { siswa }\end{array}$ & $\begin{array}{l}\text { X TKJ } 1 \\
\text { SMK } \\
\text { Maarif } 1 \\
30 \text { siswa }\end{array}$ & $\begin{array}{l}\text { X SMA } \\
\text { Muh } \\
17 \text { siswa }\end{array}$ & $\begin{array}{l}\text { X AP } \\
\text { SMK } \\
\text { PGRI } \\
17 \text { siswa }\end{array}$ & $\begin{array}{l}\text { X AK } \\
\text { SMK } \\
\text { PGRI } \\
\\
9 \text { siswa }\end{array}$ & $\begin{array}{l}\text { X TSM } \\
\text { SMK } \\
\text { Maarif } 3 \\
38 \text { siswa }\end{array}$ & $\begin{array}{l}\text { X TKR } \\
\text { SMK } \\
\text { Maarif } 3 \\
34 \text { siswa }\end{array}$ & $\begin{array}{l}\text { X SMA } \\
\text { Bokpri } \\
4 \text { siswa }\end{array}$ \\
\hline 1 & $\begin{array}{l}\text { Pemahaman } \\
\text { Konsep }\end{array}$ & 28 siswa & 29 siswa & $\begin{array}{l}17 \\
\text { siswa }\end{array}$ & $\begin{array}{l}16 \\
\text { siswa }\end{array}$ & $\begin{array}{l}9 \\
\text { siswa }\end{array}$ & 36 siswa & 31 siswa & 4 siswa \\
\hline 2 & $\begin{array}{l}\text { Persentase } \\
\text { Keberhasila } \\
\text { Pemahaman } \\
\text { Konsep }\end{array}$ & $87,5 \%$ & $97 \%$ & $100 \%$ & $97 \%$ & $100 \%$ & $95 \%$ & $91 \%$ & $100 \%$ \\
\hline 3 & $\begin{array}{l}\text { Prestasi } \\
\text { akademik } \\
\text { Rata-Rata } \\
\text { Kelas }\end{array}$ & 83 & 84 & 82 & 83 & 84 & 80 & 83 & 79 \\
\hline
\end{tabular}




\begin{tabular}{|c|c|c|c|c|c|c|c|c|c|}
\hline 4 & $\begin{array}{l}\text { Persentase } \\
\text { Prestasi } \\
\text { Akademik } \\
\text { Rata-Rata } \\
\text { Kelas }\end{array}$ & $83 \%$ & $84 \%$ & $82 \%$ & $83 \%$ & $84 \%$ & $80 \%$ & $83 \%$ & $79 \%$ \\
\hline \multicolumn{10}{|c|}{ Total Persentase Keseluruhan Keberhasilan Pemahaman Konsep Siswa : 94\% } \\
\hline
\end{tabular}

Tabel 3. Hasil Model Pengembangan Model Pembelajaran PPKn Anti Korupsi Berbasis Lingkungan Melalui Cooperative Learning

Dapat diketahui bahwa uji coba terbatas, uji coba lebih luas dan uji validitas menunjukkan peningkatan pemahaman konsep dan prestasi akademik siswa. Adapun peningkatan persentase keseluruhan keberhasilan pemahaman konsep siswa setelah uji coba model adalah 94\%. Sedangkan peningkatan persentase keseluruhan prestasi akademik siswa setelah uji coba model adalah $82 \%$.

\section{Simpulan}

Di beberapa SMA atau SMK di Kulon Progo dalam penyampaian materi PPKn oleh guru dapat diketahui antara lain 1) Persiapan guru masih kurang sebelum penerapan materi. Hal tersebut dapat dilihat antara lain kesiapan membuat perangkat pembelajaran, persiapan diri guru masih kurang. 2) guru belum sepenuhnya mengimplementasikan atau menanamkan nilai-nilai anti korupsi pada mata pelajaran PPKn. 3) pembelajaran kebanyakan di laksanakan di dalam kelas, sehingga lama kelamaan bisa jadi siswa akan bosan. 4) model yang sering di pakai oleh guru adalah ceramah, diskusi dan presentasi saja. 5) guru belum mengembangkan model dengan maksimal. dan 6) guru jarang melakukan display ruang kelas ketika pelaksanaan pebelajaran.

Adapun langkah-langkah pengembangan model adalah sebagai berikut:

\section{Tahap pertama: Pendahuluan}

Guru memberi salam kepada siswa, menanyakan keadaan siswa, dan memfokuskan siswa untuk siap belajar melalui kegiatan ice breaking dan motivasi siswa (nilai anti korupsi: jujur, disiplin, tanggung jawab, peduli).

\section{Tahap kedua: Inti Pembelajaran}

1. Penyajian secara umum meliputi: tujuan pembelajaran, penguatan pemahaman siswa, penyampaian tahapan pembelajaran dan display ruang kelas.

2. Pengajuan, membandingkan, dan menjelaskan analogi melipuri: pengajuan analogi langsung, meminta siswa membandingkan kaitan antara aspek-aspek materi yang dibahas dengan aspek yang ada dalam objek atau kegiatan yang dianalogikan, dan meminta siswa menjelaskan hasil yang dianalogikan.

3. Analogi tim meliputi meminta dan mendorong kelompok siswa mengajukan analogi, meminta kelompok siswa mendiskusikan tema dan atau topik materi, meminta kelompok siswa merangkum hasil diskusi.

4. Pengajuan analogi baru, meliputi meminta siswa melakukan pengajuan analogi baru 
terhadap materi yang di bahas, mendorong siswa agar bisa melakukan analogi baru, meminta siswa menjelaskan persamaan dan perbedaan antara aspek-aspek yang ada pada materi yang sedang di bahas dengan objek atau kegiatan yang dianalogikan. (nilai anti korupsi: jujur, disiplin, tanggung jawab, peduli).

\section{Tahap ketiga: Penutup}

Guru melakukan konfirmasi, kesimpulan dan tindak lanjut pertemuan berikutnya (nilai anti korupsi: jujur, disiplin, tanggung jawab, peduli).

Gambar 8. Langkah-langkah pengembangan pembelajaran Anti Korupsi berbasis lingkungan

Implementasi model pembelajaran PPKn anti korupsi berbasis lingkungan melalui cooperative learning di lakukan beberapa tahap. Pertama kali adalah tahap uji coba terbatas. Uji coba terbatas di terapkan pada kelas X TKR 2 SMK Maarif 1. Masih ada kekurangan dalam penerapan pada uji coba terbatas. tahap kedua adalah uji coba lebih luas diterapkan pada kelas X TKJ 1 SMK Maarif 1 dan kelas X SMA Muhammadiyah. Pada tahap ini pengajar sudah mampu menerapkan dengan baik. terakhir adalah tahap uji validasi pada kelas X AP SMK PGRI, kelas X AK SMK PGRI, X TSM SMK Maarif 3, X TKR SMK Maarif 3, dan SMA Bopkri Kulon Progo Yogyakarta. Dapat diketahui bahwa uji coba terbatas, uji coba lebih luas dan uji validitas menunjukkan peningkatan pemahaman konsep dan prestasi akademik siswa. Pemahaman konsep siswa sebelum uji coba model adalah 59\% setelah uji coba model mengalami peningkatan menjadi 94\%, sehingga peningkatan pemahaman konsep siswa adalah 35\%. Sedangkan prestasi akademik sebelum ujicoba model adalah 70,4\% setelah uji coba model menjadi 82\%. Peningkatan prestasi akademik siswa adalah $11,6 \%$.

\section{Daftar Pustaka}

Chi Huang, Tien.2011. Cooperative Weblog Learning in Higher Education: its Facilitating Effects on Social Interaction, Time Lag, and Cognitive Load. Journal Educational Technology \& Society, Volume 14 (1) halaman 01.

Daryanto.2013. Inovasi Pembelajaran Efektif. Bandung: Yrama Widya.

Kementrian Agama RI. 2013. Panduan Penyelenggaraan Pendidikan Anti Korupsi di Madrasah. Jakarta: Direktoran Jendral Pendidikan Islam.

Wahono, J., \& Anam, S. (2013). Implementasi Pendidikan Formal bagi Santri Pondok Pesantren Salaf Budi Mulyo Kaliagung Sentolo Kulon Progo 2014. Academy of Education Journal, 4(1).

Kupczynski, Lori. 2012. Cooperative Learning in Distance Learning: a Mixed Methods Study. International Journal of Intruction Volume 5 No 2 halaman 01. 
Nur Kholis, Muh. (2014). "Pengembangan Kurikulum Bermuatan Pendidikan Anti Korupsi”. Jakarta : Kementerian Agama RI Direktorat Jendral Pendidikan Islam

Nuryati, N., \& Bowo, A. N. A. (2015). Pengembangan Model Pembelajaran PPKn Quantum Teaching Berbasis Lingkungan melalui Cooperative Learning di SMA Negeri kota Yogyakarta. Academy of Education Journal, 6(2).

Perwira. 2014.Implementasi Metode Pembelajaran Guide Note Taking untuk Meningkatkan Ketuntasan Hasil Belajar Pendidikan Kewarganegaraan Siswa Kelas V SD Negeri Jetis Kecamatan Jaten. 2014. Skripsi S1 PGSD UMS.

Sarjono, Yetty dkk. 2014. Management Development Of Economics Learning that is Based on Environment With Inovative Approach at SMA Muhammadiyah Surakarta. Asia Pasific Journal of Research Vol: I Issue xiv June 2014 halaman 01.

Samawi, Ahmad dkk.,.2013. Model Pembelajaran Anti Korupsi untuk Mengembangkan Karakter Bangsa yang Bersih dari KKN dan Implementasinya dalam Pendidikan Inklusi. Journal FPPsi UM tahun 2013.

Sanjaya. 2014. Startegi Pembelajaran, Berorientasi Standar proses. Jakarta: Kencana.

Simamarta.1983.___ (di akses dalam http://damandiri.or.id pada tanggal 1 april 2015).

Sumarsono dkk. 2005. Pendidikan Kewarganegaraan. Jakarta: Gramedia Pustaka Utama.

Sutama. 2011. Metode Penelitian Pendidikan Kuantitatif, Kualitatif, PTK, R \& D. Surakarta: Fairuz.

Wahyuningsih. 2014. Upaya Peningkatan Ketuntasan Belajar Melalui Strategi Card Sort pada Materi Pelaksanaan Demokrasi dalam Berbagai Aspek Kehidupan Mata Pelajaran PKn pada Siswa Kelas VIII B SMP Negeri 2 Jatipuro Karanganyar Tahun Pelajaran 2013/2014. Skripsi S1 Univ Muhammadiyah Surakarta.

Widjojanto, Bambang. 2013. Koruptor vs Pendidikan Anti Korupsi. Jakarta: KPK.

Yamin, Martinis. 2007. Profesionalisasi Guru dan Implementasi KTSP. Gaung: Persada Perss. 